\title{
Teaching is Where It All Begins - Tout commence par l'enseignement
}

Florence Myrick

amyrick@ualberta.ca

Jacinthe I. Pepin

Université de Montréal, jacinthe.pepin@umontreal.ca

Follow this and additional works at: https://qane-afi.casn.ca/journal

Part of the Nursing Commons

\section{Recommended Citation}

Myrick, Florence and Pepin, Jacinthe I. (2017) "Teaching is Where It All Begins - Tout commence par l'enseignement," Quality Advancement in Nursing Education - Avancées en formation infirmière: Vol. 3: Iss. 1, Article 1.

DOI: https://doi.org/10.17483/2368-6669.1124

This Editorial is brought to you for free and open access by Quality Advancement in Nursing Education - Avancées en formation infirmière. It has been accepted for inclusion in Quality Advancement in Nursing Education - Avancées en formation infirmière by an authorized editor of Quality Advancement in Nursing Education - Avancées en formation infirmière. 


\section{Teaching is Where It All Begins}

As so aptly described by Britzman (2000), "learning to be a professional is not just about acquiring discrete skills and neutral knowledge that mimic the skills and knowledge of others in the same profession. Rather, professional education is more a question of whose identities, which knowledge, and which practices might be offered" (p. 38), and "in whose interest, to what end and at what cost" (Myrick et al., 2006, p. 1). Still relevant today, this perspective could be said to offer a glimpse into the role and responsibility assumed by nurse educators and the importance of what it means to teach. More specifically, it calls attention to the significance of educating nursing students for professional practice.

The teaching and learning or pedagogical process within the context of nursing education is integral to the evolution of the profession and discipline of nursing. Academic and clinical educators have an enormous responsibility to ensure that graduates develop their professional nursing identity and are prepared to competently meet the ongoing challenges and incredible vicissitudes of our time. How educators engage in nursing pedagogy contributes to the success of the student and to the profession itself, especially with regard to the safeguarding of quality health care. The stage is set for present and future nursing practice in the educational environment. It would be accurate to state that it is where it all begins! The student is afforded the opportunity to acquire the appropriate knowledge, skills, and ability to engage as a professional nurse. How that preparation is fostered is critical. Recognizing and appreciating teaching as being much more complex than the mere imparting or transmitting of knowledge is key to the success of that process (Rodriguez, 2012).

To approach teaching and learning as the imparting of knowledge could be said to actually advocate conformity resulting in students internalizing an inability to rise above their learned passivity (Myrick \& Tamlyn, 2007). Students possess unique backgrounds and experiences which educators need to genuinely recognize. To that end, students need to be actively engaged in their own learning. Accordingly then, it behooves educators to a) develop an authentic appreciation of what it means to teach vis a vis genuinely embrace the how of teaching; b) strive to create a learning environment conducive to success, one in which the student feels safe enough to question and to be questioned; and c) acknowledge students as being intelligent individuals who bring with them distinctive life experiences to their student role. "Educators must strive to ensure that current nursing curricula reflect a dynamic that democratizes rather than autocratizes, cultivates rather than curtails, liberates rather than oppresses, and honours rather than dismisses" (Myrick \& Tamlyn, 2007, p. 300). When such an approach is embraced, the educator can focus on engaging in innovation with a view to enhancing learning opportunities for all students and ultimately moving the profession of nursing forward.

\section{Tout commence par l'enseignement}

Comme l'a si bien décrit Britzman, apprendre à devenir professionnel ne signifie pas seulement acquérir des habiletés isolées et des connaissances neutres qui imitent les habiletés et les connaissances d'autres personnes exerçant la même profession. L'enseignement professionnel est plutôt une question de savoir quelles identités, connaissances et pratiques doivent être offertes (Britzman, 2000, p. 38) et dans quel intérêt, à quelle fin et à quel prix (Myrick et coll., 2006, p. 1). Toujours pertinent de nos jours, ce point de vue offre un aperçu des responsabilités et du rôle des infirmières enseignantes et de l'importance de ce que signifie 
« enseigner ». Il souligne également l'importance de former les étudiantes infirmières pour la pratique professionnelle.

Les processus d'enseignement et d'apprentissage dans un contexte de formation en sciences infirmières sont essentiels à l'évolution de la profession et de la discipline infirmières. Les formatrices des milieux d'enseignement et de soins endossent d'énormes responsabilités pour s'assurer que les diplômées développent leur identité professionnelle infirmière et soient en mesure de mettre leurs compétences à contribution afin de surmonter les défis constants et les aléas du temps présent. La façon dont les enseignantes s'impliquent en pédagogie des sciences infirmières contribue au succès des étudiantes et à la profession même, plus particulièrement en matière de maintien et d'amélioration de la qualité des soins de santé. La table est mise pour le présent et l'avenir de la pratique des soins infirmiers dans un environnement éducatif. Il serait juste de dire qu'il s'agit de la base de tout. Les étudiantes ont la possibilité d'acquérir les connaissances et développer les aptitudes et les compétences essentielles pour exercer en tant qu'infirmières professionnelles. La façon dont cette préparation est guidée est cruciale. Reconnaître et appréhender l'enseignement comme étant beaucoup plus complexe que la transmission de savoirs est la clé du succès de ce processus (Rodriguez, 2012).

Le fait de considérer l'enseignement et l'apprentissage comme un transfert de connaissances soutiendrait la conformité, empêchant ainsi les étudiantes de s'élever au-dessus d'une passivité inculquée (Myrick et Tamlyn, 2007). Les professeures doivent véritablement reconnaître que les étudiantes proviennent de milieux divers, ont vécu des expériences différentes et ainsi, favoriser la participation active des étudiantes à leur apprentissage. Par conséquent, il incombe aux enseignantes de : a) développer une réelle appréciation de ce que signifie l'enseignement et de l'importance de s'engager dans le «comment» enseigner ; b) chercher à créer un environnement d'apprentissage qui favorise le succès, dans lequel les étudiantes se sentent suffisamment en confiance pour poser des questions et fournir des réponses; et c) reconnaître l'intelligence des étudiantes qui apportent leur propre bagage de vie dans leur apprentissage. «[Traduction] Les enseignantes doivent s'assurer que le curriculum en sciences infirmières reflète une dynamique qui démocratise plutôt qu'autocratise, cultive plutôt que restreint, libère plutôt qu'oppresse et honore plutôt que de rejette » (Myrick et Tamlyn, 2007, p. 300). Lorsqu'une telle approche est adoptée, l'enseignante peut se centrer sur l'innovation afin d'améliorer les occasions d'apprentissage pour toutes les étudiantes, et ultimement aider à l'avancement de la profession infirmière.

Cordialement / Respectfully,

Corédactrices en chef, Co-Editors-in-Chief,

Jacinthe Pepin, inf. Ph.D., Faculté des sciences infirmières, Université de Montréal

Florence Myrick, RN, Ph. D., Faculty of Nursing, University of Alberta 


\section{References / Références}

Britzman, D. P. (2000). Teacher education in the confusion of our times. Journal of Teacher Education, 51(3), 200-205. doi: https://doi.org/10.1177/0022487100051003007

Myrick, F., \& Tamlyn, D. (2007). Teaching can never be innocent: Fostering an enlightening educational experience. Journal of Nursing Education, 46(7), 299-303.

Myrick, F., Phelan, A., Barlow, C., Sawa, R., Rogers, G., \& Hurlock, D. (2006). Conflict in the preceptorship or field experience: A rippling tide of silence. International Journal of Education Scholarship, 3(1), 1-14. doi:https://doi.org/10.2202/1548-923x.1202

Rodriguez, V. (2012). The teaching brain and the end of the empty vessel. Mind, Brain and Education, 6(4), 177-185. doi:https://doi.org/10.1111/j.1751-228x.2012.01155.x 